\title{
MEMBANGUN KEMANDIRIAN MELALUI FILANTROPI KAUM PEREMPUAN; \\ Potensi Kedermawanan untuk Pemberdayaan Perempuan Indonesia
}

\author{
Abdurrohman Kasdi \\ Institut Agama Islam Negeri Kudus \\ abdurrohmankasdi@iainkudus.ac.id
}

\section{ABSTRAK}

Artikel ini mengkaji tentang potensi filantropi kaum perempuan untuk membangun kemandirian dan pemberdayaan perempuan Indonesia dalam bentuk studi dokumentasi. Hasil penelitian menunjukkan bahwa kedermawanan perempuan Indonesia mengalami perkembangan yang signifikan. Kedermawanan ini melibatkan banyak aspek dalam pengejawantahan kegiatan filantropi kaum perempuan. Dengan mengerahkan semua potensi yang ada, perempuan pelaku filantropi menunjukkan kepada masyarakat bahwa perhatian terhadap orang-orang yang kekurangan dan membutuhkan bantuan sangat penting. Kaum perempuan bisa menggerakkan berbagai potensi yang dimilikinya untuk menjadi fundraiser, volunteer, campaigner, bahkan menjadi donatur untuk lembaga sosial di masyarakat.Aktivitas filantropi untuk kemandirian perempuan sangat berpotensi dengan cara mengoptimalkan potensi kaum perempuan itu sendiri sebagai pendukung dan donatur program tersebut. Bahkan filantropi kaum perempuan menjadi kontribusi yang signifikan baik secara sosial maupun ekonomi, yang menunjukkan peran perempuan sebagai agen perubahan sosial.

Kata kunci: Filantropi, Kemandirian, Pemberdayaan, Perubahan Sosial 


\section{ABSTRACT}

This article aims to elaborate the potency of women's philanthropy to build the independence and empowerment of Indonesian women.This studi uses library research. The results of this study indicate that the generosity of Indonesian women experiece significant development. As a resource in the manifestation of women's philanthropic activities, the generosity involves many aspects. By mobilizing all the potencies they have, female philanthropists show the community that attention to people who are in need is important. Women can move their potencies to become fundraisers, volunteers, campaigners, and even become donors to social institutions in the community. Philanthropic activities for women's independence are very potential by optimizing the potencies of women themselves as supporters and donors of the program. Even women's philanthropy is a significant contribution both socially and economically, which shows the role of women as agents of social change.

Keywords: Philanthropy, Independence, Empowerment, Social Change

\section{A. Pendahuluan}

Relasi antara perempuan dan filantropi ternyata sangat erat dan tidak dapat dipisahkan. Oleh karena itu, filantropi hendaknya digalakkan untuk mendukung upaya kemandirian perempuan. Hal ini penting untuk dilakukan karena pembangunan nasional belum bisadirasakan secara setara bagi perempuan. Mereka masih tertinggal dibandingkan laki-laki dalam beberapa bidang kehidupan. Bidang kesehatan contohnya, masalah yang dihadapi perempuan terkait tingginya angka kematian ibu dan kesehatan reproduksinya. Pada bidang pendidikan, kaum perempuan masih belum setara dibandingkan laki-laki. Sedangkan di bidang ekonomi, secara umum kemampuan perempuan dalam mengakses peluang kerja masih rendah, 
demikian halnya dengan kesempatan untuk mendapatkan kehidupan yang layak. Karena itu, perempuan memerlukan dukungan khusus dari semua lapisan masyarakat untuk melakukan kegiatan filantropi.

Perempuan memiliki kekuatan sosial sangat besar yang berdasar pada sifat kasih sayangnya, namun institusionalisasi sosial dan politik dibangun di atas kekuasaan maskulin. Kenyataan kehidupan masyarakat yang keras ini membuat perempuan lebih mandiri, sekaligus tidak melupakan sisi welas asih perempuan dan tanggung jawab sosialnya untuk memikirkan orang lain. Hal ini diwujudkan dalam bentuk kedermawanan perempuan yang tercermin dalam penggalangan sumber daya dan pendistribusiannya untuk masyarakat yang kekurangan dan membutuhkan bantuan. Kedermawanan perempuan ini menjadi relevan dan sangat urgen untuk dikembangkan dan didukung oleh berbagai kalangan.

Tingkat kepedulian dan kedermawanan sosial masyarakat yang tinggi memberikan kesempatan bagi berkembangnya kegiatan fundraising dan pendistribusian dana sosial untuk mendukung filantropi. Upaya-upaya penggalangan danauntuk kegiatan filantropi dilakukan oleh berbagai macam organisasidi beberapa tempat, terutama di waktu-waktu yang telah ditentukan, seperti ketika terjadi bencana alam. Kegiatan pengumpulannya pun tidak lagi dilakukan dengan cara tradisional, tapi sudah mengarah pada filantropi modern.

Kegiatan pengumpulan ini tidak hanya dilakukan oleh laki-laki tetapi juga perempuan. Ini dilakukan berdasarkan pada sebuah konsep gender yang juga menjadi perhatian dalam kehidupan filantropi. Kata gender dimaknai secara etimologi sebagai jenis kelamin (Echols \& Shadily, 1983: 265). Sedangkan secara terminologi, gender adalah suatu konsep kultural yang berupaya membuat distingsi dalam 
peran, perilaku, mentalitas, dan karakteristik emosional antara perempuan dan laki-laki yang berkembang di masyarakat. Kata gender juga sering diartikan sebagai relasi antara perempuan dan laki-laki dilihat dari segi nilai dan perilaku (Neufeldt, 1984: 561).

Definisi ini menunjukkan bahwa gender merupakan salah satu bentuk interaksi sosial antara perempuan dan laki-laki. Hal ini diperkuat dengan fakta yang menunjukkan bahwa secara sosiologis gender adalah model hubungan sosial yang terorganisir antara perempuan dan laki-laki yang tidak semata-mata hanya hubungan personal dan kekeluargaan, melainkan meliputi institusi sosial yang lebih luas seperti status sosial, hubungan hierarki dalam pekerjaan dan struktur organisasi di masyarakat (Borgatta \& Borgatta (ed.), 1984: 748). Sedangkan pemberdayaan merupakan sebuah proses pelibatan kemandirian di antara anggota organisasi melalui identifikasi kondisi yang mendorong ketidakberdayaan menjadi berdaya-guna melalui proses regenerasi dan praktik-praktik kaderisasi informal dalam menjaga keberlangsungan kegiatannya (Conger \& Kanungo, 1988: 482). Pemberdayaan dapat dianalisis melalui aksi-aksi warga baik di tingkat individu maupun organisasi serta proses timbal balik dalam sebuah komunitas. Oleh karena itu, pemberdayaan merupakan partisipasi dalam proses pengambilan kebijakan serta proses untuk menerima kapasitas diri sebagai seorang yang cakap dan berhak untuk membuat keputusan-keputusan (Rowlands, 1997: 14).

Gagasan tentang pengarusutamaan gender (gender mainstreaming) bertujuan untuk pemberdayaan perempuan. Ide ini merupakan strategi untuk mencapai keadilan gender dan kesetaraan melalui kebijakan dan program yang melibatkan aspirasi, kebutuhan, pengalaman, dan permasalahan kesetaraan antara perempuan dan laki- 
laki. Hal ini karena proses pembangunan yang berjalan hendaknya melibatkan hak dan peluang bagi semua orang, tanpa membedakan status sosial dan gender, untuk mengakses hasil pembangunan tersebut. Munculnya hak sipil (civil right) yang turut menyumbang bagitumbuhnya gerakan sosial (social movement), sebenarnya tidak dapat dilepaskan dari perjuangan kesetaraan ras dan gender.

Fenomena ini kemudian disusul dengan bangkitnya gerakan pembebasan dan pemberdayaan perempuan untuk menolak pola tradisional yang mendudukkan pria lebih dominan dalam ruang publik (Turner, 1998: 550). Gerakan menuntut kesetaraan hak sipil ini bisa dilihat sebagai gerakan sosial yang aktual pada zamannya dan menarik perhatian masyarakat. Dorongan dari akademisi dan kaum intelektual ini turut memastikan teori-teori yang meruntuhkan diskriminasi terhadap ras dan gender. Sehingga yang berjalan adalah lebih ke arah kesetaraan identitas yang berdampak pada terbukanya kesamaan akses terhadap kepentingan masyarakat.

Penelitian ini berupaya menelaah semangat filantropi perempuan, relasi kekuasaan dan kapasitas institusional dalam membentuk watak dan karakteristik kedermawanan kaum perempuan. Tujuan penelitian adalah untuk mengurai dinamika filantropi perempuan dan dialektikanya, terutama jika dikaitkan dengan upaya membangun kemandirian kaum perempuan. Penelitian ini melengkapi potret atas pengalaman perempuan sebagai pelaku filantropi baik untuk kebutuhan perempuan itu sendiri secara khusus misalnya melalui kegiatan sosial yang mengarah pada kemandirian perempuan maupun manfaat filantropi bagi masyarakat umum. Pengalaman perempuan layak dijadikan sebagai women standpoint dalam melihat dan membincangkan problem relasi gender yang berkeadilan dan berkesetaraan. 
Metode yang digunakan dalam penelitian ini menggunakan penelitian kualitatif dengan pendekatan fenomenologi (Muhajir, 1994: 13). Langkah yang dilakukan yaitu dengan mengidentifikasi pengalaman-pengalaman kaum perempuan dan lembaga filantropi sebagai fenomena yang ingin digambarkan dalam penelitian artikel ini (Creswell, 2003: 15). Lembaga dan perorangan pelaku filantropi kaum perempuan yang menjadi obyek dalam penelitian ini adalah mereka yang sudah lama akrab dan berkecimpung dalam dunia kedermawanan, filantropi dan karitatif. Mereka adalah masyarakat secara luas yang konsen dengan pemberdayaan perempuan atau perempuan itu sendiri yang terjun dalam dunia filantropi dan berupaya untuk menggerakkan potensi yang dimilikinya. Karena filantropi untuk kemandirianperempuan sangat berpotensi jika dilaksanakan dengan memanfaatkan potensi yang dimiliki kaum perempuan sebagai pendukung program tersebut.

\section{B. Pembahasan}

\section{Potensi Filantropi di Indonesia}

Filantropi merupakan proses dialektika antara seseorang dengan orang lain, cinta, rahmat dan keadilan, kerelawanan dan kewajiban, serta bantuan dan pengembangan (Payton, 1998:39). Secara etimologi, filantropi berasal dari bahasa Yunani: philos yang berarti cinta dan anthropos yang berarti love of people. Sedangkan secara terminologi, filantropi diartikan dengan rasa kecintaan kepada manusia yang terpatri dalam bentuk pemberian derma kepada orang lain(Ilchman, 2006:viiviii). Oleh karena itu, filantropi adalah konseptualisasi dari praktik penyediaan layanan sukarela (voluntary services), pemberian sumbangan sukarela (voluntary giving) 
dan asosiasi sukarela (voluntary association) secara suka rela untuk membantu pihak lain yang membutuhkan sebagai ekspresi rasa cinta dan kasih sayang.

Istilah filantropiIslam menunjukkan adanya praktik filantropi dalam tradisi Islam melalui zakat, infak, sedekah, dan wakaf (Zahrah, 2005:25). Dalam ayat alQur'an (QS. al-Bayyinah: 4-6), ada tiga perintah yang harus diimplementasikan oleh setiap Muslim, yaitu menyembah Allah semata tanpa menyekutukannya, melaksanakan ibadah secara teratur, dan mempraktikkan kedermawanan secara teratur. Allah menyuruh seorang Muslim untuk berfilantropi supaya harta kekayaan tidak hanya berputar di kalangan orang-orang kaya (QS. al-Hasyr: 7). Pentingnya filantropi Islam bisa dilihat dari cara al-Qur'an menekankan keseimbangan antara zakat dan shalat. Begitu tegasnya perintah mengenai zakat, al-Qur'an mengulang sebanyak 72 kali perintah zakat (ita' az-zakât) dan menggandengkannya dengan perintah salat (iqam ash-shalat)(Kasdi, 2016: 230).

Dasar filosofi filantropi adalah menjaga harkat dan martabat manusia, tindakan berderma harus dilakukan dengan cara-cara yang moderat dan tidak berlebihan (QS. alFurqan: 67). Dalam memberikan derma pemberi sama sekali tidak boleh menyebabkan penerima merasa dipermalukan apalagi terhina (QS. al-Baqarah: 264). Al-Qur'an juga secara khusus menekankan pentingnya memberikan derma berupa barang-barang yang disukai, yang baik-baik, bukan yang buruk-buruk (QS. al-Baqarah: 267). Oleh karena itu, konsep filantropi dalam al-Qur'an sejatinya mengandung nilai-nilai kemurahan hati, keadilan sosial, saling berbagi, dan saling memperkuat antar sesama.

Islam mengajarkan bahwa memberikan sebagian harta dalam bentuk filantropi kepada orang yang tidak mampu merupakan doktrin yang sangat penting. Filantropi dipraktikkan umat Islam dalam bentuk zakat, sedekah, 
infak maupun wakaf, tetapi menurut Miriam Hoexter yang paling efektif dalam membangun kemandirian umat Islam adalah wakaf (Hoexter, 2003: 145). Di era sekarang, filantropi Islam dipahami sebagai bagian dari tradisi kedermawanan yang keberlangsungannya dibentuk bukan hanya oleh keyakinan doktrinal, tetapi juga oleh faktor ekonomi,politik, sosial dan budaya yang mempengaruhi perkembangan masyarakat (Bakar \& Bamualim (ed.), 2006: ix).

Menjadi filantropis tidak selamanya harus dari orang kaya atau berasal dari keluarga kaya. Sebab kegiatan ini bisa dilakukan oleh mereka yang memiliki kemampuan mencapai sesuatu dan kemudian menyumbangkannya kepada masyarakat sekitar, meskipun mereka bukanlah orang yang kaya. Sehingga filantropi dalam arti pemberian derma bisa juga disamakan dengan istilah karitas (charity) dan lebih dikaitkan dengan proses "sharing private resources untuk public benefit" (Klein, 2001: 5). Private resources di sini tidak harus dimaknai dengan uang, tapi bisa dalam bentuk sumber daya lainnya, seperti pikiran, tenaga dan benda.

Upaya penguatan civil society dalam rangka perubahan sosial di Indonesia mendapatkan momentum di tengah hiruk pikuk reformasi di negeri ini. Penguatan ini terjadi manakala ada kemandirian organisasi civil society, terutama dalam hal pendanaan yang dapat menjamin keberlangsungan aktivitas dan prakarsa perubahan sosial yang diembannya. Sejalan dengan hal itu, kita menyaksikan tumbuhnya lembaga-lembaga filantropi yang dikelola oleh masyarakat baik yang murni swasta maupun yang diprakarsai oleh pemerintah.

Kegiatan filantropi sebenarnya telah menjadi tradisi dan kebiasaan masyarakat Indonesia. Hasil survei Center for the Study of Religion and Culture (CSRC) UIN Jakarta dan survei Public Interest Research and Advocacy Center 
(PIRAC) menunjukkan bahwa hampir semua masyarakat Muslim Indonesia pernah berderma (Saidi (et.al.), 2002: 48). Meskipun nilainya tidak sama, namun hampir semua pernah menyumbang, baik dalam bentuk zakat, infak, sedekah maupun wakaf. Jika ditotal, ternyata uang yang mereka dermakan sebagai zakat, infak dan sedekah mencapai sekitar 19,3 triliun per tahun(Bakar \& Bamualim (ed.), 2006:3). Sedangkan wakaf sebagai penopang kekuatan ekonomi umat Islam jika diakumulasikan menjadi potensi besar dari aset wakaf (Kasdi, 2018: 1841). Data dari Kementerian Agama menunjukkan bahwa jumlah tanah wakaf di Indonesia mencapai 2.686.536.656 meter persegi atau sekitar 268.654 hektar (ha) yang tersebar di seluruh Indonesia. Selain itu, aset nasional ekonomi wakaf sangat besar, mencapai 590 Triliun (Depag, 2006: 83).

Potensi dan pola perilaku menyumbang masyarakat Indonesia sebagai sumber dana dan sumber daya, serta polapola penggalangan dana yang dilakukan oleh lembaga sosial juga diteliti oleh PIRAC dengan dukungan APPC. Mereka melakukan survey rumah tangga di sejumlah kota besar di Indonesia dan studi kasus untuk mendokumentasikan berbagai model dan strategi yang digunakan organisasi sosial dalam menggalang dana masyarakat. Berdasarkan temuan penelitian ini ditemukan data potensi kultural sekaligus potensi ekonomi dalam kegiatan filantropi masyarakat Indonesia (Saidi (et.al.), 2002: 3-4). Filantropi di Indonesia mengalami perkembangan yang signifikan, ditandai dengan: pertama, meningkatnya antusiasme umat dalam berfilantropi yang ditunjukkan dengan lahirnya sejumlah organisasi maupun aktor-aktor baru filantropi Islam. Kedua, pengelolaan dana Zakat Infak, Sedekah dan Wakaf (ZISWAF). Dulu panitia zakat di masjid-masjid lebih banyak diisi orang-orang yang sudah tua dengan latar belakang pendidikan dan pengalaman yang pas- 
pasan, namun kini pengelolaan filantropi Islam di sejumlah lembaga pada umumnya digerakkan oleh anak-anak muda yang terdidik, berbakat dan trampil. Ketiga, perkembangan ini juga dipengaruhi oleh revitalisasi visi dunia filantropi Islam, yang mencoba mentransformasikan paradigma lama filantropi dengan paradigma baru yang lebih kreatif dan inovatif(Bakar \& Bamualim (ed.), 2006: viii).

Tradisi dan budaya masyarakat Indonesia juga sangat mendukung berkembangnya kegiatan filatropi. Masyarakat jawa misalnya masih melakukan tradisi jimpitan dan sinoman. Orang-orang Sunda juga mempunyai budaya serupa yang disebut parelek, sedangkan warga Minang mengenal tradisi julo-julo. Sejumlah organisasi modern memanfaatkan tradisi ini untuk menggalang fundraising dan partisipasi masyarakat. Tradisi kedermawanan masyarakat Indonesia mengilhami program-program filantropi, seperti credit union, dana hari tua dan solidaritas kesehatan yang diprogram dan disosialisasikan dengan pendekatan budaya dan tradisi setempat. Strategi yang sama juga dilakukan oleh Yayasan Tengko Situru yang mengumpulkan dana dan sumber daya dengan pendekatan budaya dan tradisi adat Toraja (Saidi (et.al.), 2002: 9).

Eksistensi Lembaga Filantropi pada ormas-ormas Islam sepertiNahdhatulUlama(LazisNU), Muhammadiyah (LazisMU) dan lainnya yang ditopang dengan dana filantropi, juga membuktikan semakin kuatnya tradisi filantropi dalam masyarakat Indonesia (Fauzia, 2017: 225). Bahkan kegiatan ini pada tahap berikutnyabisa diarahkan melalui usaha untuk membangun SDM bangsa melalui kegiatan pendidikan umat Islam, khususnya di tingkat perguruan tinggi. Dengan berdirinya Yayasan Wakaf Perguruan Tinggi Islam Jakarta dan Badan Wakaf Universitas Islam Indonesia (UII) di Yogyakarta yang kini mengelola Universitas Islam Indonesia,kemudiandisusul 
berdirinya Yayasan Badan Wakaf Sultan Agung (YBWSA) yang mendirikan Universitas Islam Sultan Agung (UNISSULA). Sedangkan di kalangan pondok pesantren terjadi langkah penting dengan adanya ikrar penyerahan wakaf yang menandai disahkannya Badan Wakaf Pondok Modern Gontor (Zarkasyi, 2005: 186).

Kegiatan filantropi masyarakat Indonesia dalam bentuk zakat, infak, sedekah, dan wakaf bertujuan memperkuat relasi sosial, karena zakat pada dasarnya bertujuan meneguhkan interaksi di antara muslim melalui praktik filantropi orang yang kaya terhadap orang miskin. Tampak jelas bahwa filantropi berperan memberikan kontribusi pada rasa kepemilikan atas kesatuan umat dan penguatan solidaritas sosial bagi masyarakat. Memberikan zakat merupakan bagian dari komitmen seorang Muslim terhadap agama dan nilai-nilai keadilan sosial. Demikian juga wakaf, yang telah bermetamorfosis menjadi ribuan mushalla,masjid, madrasah, pesantren, sekolah, rumah sakit, dan lain sebagainya (Shabri, 2008: 341-447). Wakaf merupakan pranata sosial dalam Islam yang mempunyai keterkaitan langsung dengan usaha pemecahan masalah sosial dan kemanusiaan, seperti jaminan sosial, pengentasan kemiskinan, pemberdayaan ekonomi umat, dan peningkatan sumber daya manusia (Kasdi, 2018: 18411844). Hal ini karena wakaf memiliki potensi besar dalam mewujudkan tata sosial masyarakat yang berkeadilan (Qahaf, 2006: 284).

Pemerintah Indonesia juga memberikan perhatian terhadap filantropi dengan mendorong terbentuknya organisasi pelaksana, pertimbangan dan pengawasan, dan ujungnya terbentuklah Badan Amil Zakat Infak dan Sedekah (BAZIS) melalui Surat Keputusan Gubernur Daerah Khusus Ibukota Jakarta, Ali Sadikin, No. Cb14/8/18/1968 pada tanggal 5 Desember 1968, kemudian 
diikuti oleh beberapa propinsi di Indonesia (Salim, 2003: 158). Perkembangan filantropi Islam semakin berkembang pada saat krisis ekonomi melanda bangsa Indonesia dan terbukanya suasana demokrasi di era reformasi. Saat itu merupakan puncak dari pelembagaan filantropi Islam dengan dikeluarkannya peraturan pemerintah dan undang-udang mengenai pelaksanaan filantropi Islam. Dua undang-undang yang sangat relevan adalah Undangundang Zakat (1999) yang mengatur pelaksanaan zakat dan Undang-undang Wakaf (2004) yang mengatur pelaksanaan wakaf. Selain itu, muncul aspirasi masyarakat untuk mengelola zakat dengan profesional melalui lembaga zakat, baik yang dibentuk oleh pemerintah yaitu Badan Amil Zakat Nasional (BAZNAS) dan Badan Amil Zakat Daerah (BAZDA) maupun yang dibentuk oleh masyarakat yaitu Lembaga Amal, Zakat Infak dan Shodaqoh (LAZIS).

Keinginan untuk merevitalisasi peran zakat dan wakaf menuntut keterlibatan pemerintah dengan membentuk BAZNAS dan BAZDA. Dalam hal zakat, selain terlibat dalam pengumpulan dan pengelolaan zakat, pemerintah juga berusaha melakukan promosi peraturan dan undang-undang yang mengatur tentang pengelolaan zakat. Sementara itu juga muncul inisiatif dari kalangan swasta untuk mengelola dana zakat dari masyarakat. Dalam kegiatannya, LAZIS yang dikelola oleh swasta tampaknya mendapat kepercayaan dari masyarakat dan lebih maju dibandingkan BAZNAS yang dikelola pemerintah (Bakar \& Bamualim (ed.), 2006: 103). Selain itu, ada beberapa lembaga baru yang memiliki perhatian utama dalam filantropi Islam, yaitu: Yayasan Dompet Dhuafa yang dibentuk oleh sebagian karyawan Republika untuk merespon kelaparan yang hebat di Indonesia, Pos Keadilan Peduli Umat yang lahir untuk merespon berbagai bencana alam yang merajalela di Indonesia, Dompet Sosial Ummul 
Qura', dan Yayasan Dana Sosial al-Falah. Demikian juga, hadirnya program-program dan asosiasi yang bergerak di bidang filantropi seperti Rumah Zakat, Forum Zakat, Tabung Wakaf, Lembaga Kesehatan Cuma-Cuma, dan lainnya. Semua lembaga itu memanfaatkan dana filantropi untuk tujuan pemebrdayaan masyarakat.

\section{Filantropi sebagai Pilar Pemberdayaan Perempuan}

Sejalan dengan semangat kedermawanan masyarakat Indonesia, kedermawanan perempuan Indonesia juga tengah mengalami perkembangan yang signifikan. Kedermawanan ini melibatkan banyak aspek sebagai resource dalam pengejawantahan kegiatan filantropi mereka. Dengan mengerahkan semua potensi yang ada, para pelaku filantropi perempuan menunjukkan kepada masyarakat bahwa perhatian terhadap orang-orang yang kekurangan dan membutuhkan bantuan sangat penting. Bentuk perhatian ini tidak hanya dibatasi oleh materi dan kebutuhan jangka pendek, melainkan penanaman nilai dan semangat perubahan ke arah yang lebih baik.

Upaya untuk mendukung kegiatan filantropi dalam rangka pemberdayaan perempuan adalah melalui kegiatan penggalangan dana (fundraising). Kegiatan penggalangan dana ini tidak hanya penting, melainkan sudah menjadi ruh pada semua kegiatan filantropi. Aktivitas fundraising mampu mengarahkan dan mendorong masyarakat untuk kegiatan berderma padaprogram-programyang diinginkan. Bahkan strategi penggalangan dana merupakan kegiatan penting dalam kegiatan filantropi untuk pemberdayaan dan kemandirian perempuan. Upaya untuk mendorong kegiatan tersebut bisa dilakukan dengan mencurahkan perhatian pada beberapa aspek dalam fundraising agar lebih memihak pada pemberdayaan perempuan.

Filantropi sebagai upaya pemberdayaan perempuan 
merupakan sesuatu yang harus dilakukan karena beberapa hal; pertama, berdasarkan data statistik jumlah perempuan lebih banyak dibandingkan laki-laki. Itu berarti setiap kebijakan yang diambil lebih banyak menyangkut nasib perempuan. Kedua, secara psikologis jiwa perempuan lebih peka dan lebih sensitifdibandingkanlaki-laki. Kepekaan dan sensitifitas yang dimiliki perempuan ini merupakan modal penting dalam menumbuhkan kepedulian dengan sesama. Ketiga, jiwa keibuan sangat identik dengan kemampuan dan kerelaan untuk mendidik, sedangkan pendidikan adalah kunci pembentukan sikap baik. Keempat, secara sosiologis ibu atau perempuan merupakan orang yang paling mengetahui kondisi dan kebutuhan keluarganya. Dalam skala yang lebih luas, berarti mereka adalah orang yang paling mengetahui kondisi dan kebutuhan masyarakatnya. Kelima, kesabaran dan keprihatinan yang dimiliki perempuan jauh lebih tinggi dibandingkan lakilaki. Sehingga mereka memiliki potensi yang lebih besar dalam mengendalikan program kedermawanan dan pemberdayaan (Westy, 2008: 15-16).

Pemberdayaan perempuan yang dilakukan oleh lembaga maupun individu yang berbasis filantropi awalnya dibangun dengan kerelawanan dan aktualisasi diri. Kegiatan ini butuh proses identifikasi diri yang mirip dengan apa yang disebut Maslow sebagai hirarki kebutuhan (hierarchy of needs). Pelaku filantropi mengkategorisasikan kebutuhan akan aktualisasi diri, sekaligus rasa cinta dan kasih sayang kepada orang yang membutuhkan (Maslow, 1970: 56-57).

Sampai saat ini kerelawanan perempuan menjadi modal utama dalam kerja-kerja pemberdayaan perempuan yang mereka lakukan. Sebagai contoh, dalam masa darurat bencana, berdirinya dapur umum dan bantuan makanan cepat saji dalam waktu cepat merupakan bukti kontribusi 
sekaligus kesigapan perempuan dalam memberikan bantuan terhadap korban bencana. Hanya saja, ketiadaan sosialisasi bagi kerelawanan perempuan ini mengakibatkan kapasitas dan kontribusi mereka tidak diperhitungkan.

Beberapa program pemberdayaan berbasis filantropi yang dilakukan oleh perempuan adalah; pertama, SAPA Institute yang dirintis oleh sekelompok kaum muda perempuan yang memiliki perhatian terhadap isu-isu perempuan. Organisasi yang diinisiasi di Bandung sejak 25 Juni 2002 ini awalnya merupakan kelompok diskusi tentang hubungan antara Gender, Islam dan Feminisme. Pada perkembangan berikutnya, SAPA Institute terlibat pada upaya pemberdayaan perempuan di bidang pendidikan, sosial, budaya, ekonomi, dan politik. Tahun 2005, mereka melibatkan diri pada isu-isu pengembangan masyarakat terutama pemberdayaan perempuan agar mereka mampu memahami dan memperjuangkan hakhaknya (Westy, 2008: 22-23).

Kedua, Migrant Care yang saat ini telah membentuk DESBUMI (Desa Peduli Buruh Migran) di 41 desa. DESBUMI merupakan inisiatif untuk melindungi buruh migran, khususnya buruh migran perempuan, yang dimulai dari tingkat desa. DESBUMI dimotori oleh mantan buruh migran perempuan, keluarganya, aparat desa dan calon buruh migran. Menurut Anis Hidayah, Direktur Migrant Care, kelompok-kelompok perempuan buruh migran di desa menjadi sumber informasi bagi calon buruh migran agar mereka siap bermigrasi secara aman. Desa menjadi penjaga utama untuk memastikan kalau warganya bermigrasi secara aman (Hidayah, 2018).

Ketiga, PEKKA (Pemberdayaan Perempuan Kepala Keluarga). PEKKA adalah programkemitraan yang bekerja di lebih dari 800 desa di 20 provinsi. PEKKA mendidikperempuan-perempuandidesa, yangkemudian 
membantu perempuan lainnya agar dapat mengikuti program-program perlindungan sosial pemerintah bagi perempuan, seperti BPJS, PKH, KIS, KIP dan memiliki penghidupan yang lebih layak. Menurut Romlawati dari PEKKA bahwa praktik PEKKA ini memperluas makna filantropi yang selama ini dikenal, yaitu mereka yang berpunya menyumbangkan uang atau sumber daya lain untuk tujuan-tujuan mulia. Kelompok-kelompok perempuan yang bekerjasama dengan PEKKA telah memberikan waktu, tenaga bahkan uang atau materi lainnya. Ini menandakan bahwa filantropi adalah bagian dari perempuan dengan memobilisasi sumber daya oleh perempuan(Romlawati, 2018).

Keempat, MAMPU (Maju Perempuan Indonesia untuk Penanggulangan Kemiskinan). Ini merupakan program penanggulangan kemiskinan perempuan yang didirikan oleh Pemerintah Indonesia dan Pemerintah Australia. Saat ini Program MAMPU sudah menjangkau sekitar 2.000 kelompok perempuan yang berada di 1.600 desa, tersebar di 175 kabupaten/kota dan 26 provinsi di Indonesia. MAMPU bekerjasama dengan 133 organisasi. MAMPU bertujuan untuk meningkatkan jaringan perempuan miskin di di Indonesia untuk mendapatkan layanan dasar dan penghidupan yang lebih baik. MAMPU fokus pada lima tema yaitu: meningkatkan akses perempuan terhadap program perlindungan sosial pemerintah, meningkatkan akses perempuan terhadap pekerjaan dan menghapus diskriminasi di tempat kerja, memperbaiki kondisi perempuan pekerja migran, memperkuat kepemimpinan perempuan untuk meningkatkan kesehatan ibu dan reproduksi dan memperkuat kepemimpinan perempuan untuk mengurangi kekerasan terhadap perempuan (www. mampu.or.id). 
Kelima, Suara Ibu Peduli (SIP). SIP pertama terbentuk pada 23 Februari 1998 saat terjadi aksi protes kenaikan susu. Ratusan ibu-ibu kelas menengah atas dari seluruh penjuru Jakarta secara sukarela bergerak mencari dan menyalurkan susu untuk bayi dan balita anak keluarga yang tak mampu. Gerakan spontan para ibu rumah tangga ini tidak berhenti di susu saja dan ternyata bertahan lama. Sekarang ini gerakan tersebut mulai menangani salah satu dimensi kemiskinan yaitu ketidakmampuan membeli kebutuhan pokok (Westy, 2008: 16-17).

Kiprah para perempuan di atas dalam kegiatan filantropi menunjukan kepada kita tentang peran pemberdayaan perempuan dalam gerakan membangun masyarakat yang lebih manusiawi di negeri ini. Mereka seolah menegaskan bahwa perempuan adalah born organizers (pengorganisir alamiah). Apa yang dilakukan oleh kaum perempuan di atas memberi makna tentang eksistensi perempuan yang mempunyai kemampuan menyelenggarakan sekian jenis pekerjaan dan menciptakan ruang lebih luas untuk menhgajak setiap orang, baik laki-laki ataupun perempuan, mengurus bukan hanya kesejahteraannya sendiri, melainkan juga kesejahteraan masyarakat.

\section{Dari Filantropi Menuju Kemandirian Perempuan}

Perhatian khusus terhadap filantropi untuk kemandirian perempuan ini perlu digalakkan karena selama ini perempuan belum dianggap sebagai donatur yang prospektif. Perempuan diasumsikan sebagai bagian dari kalangan yang berada di sektor privat, sehingga sektor publik lebih dominan dikuasai laki-laki. Sehingga tidak heran jika peremuan dikategorikan sebagai kelompok marginal. Perempuan dimasukkan dalam kelompok 
subaltern, yang selama ini tidak terakomodasi dalam struktur sosial yang dipenuhi dengan maskulinitas (Gandi, 1998: 1).

Perempuan dianggap belum memiliki harta atau penghasilan sebesar laki-laki. Perempuan juga dinilai tidak punya kewenangan dalam pengambilan keputusan berderma, karena orang yang memberi nafkah dalam keluarga sebagian besar adalah laki-laki yang juga berperan sebagai kepala keluarga. Ketika suara mereka tidak didengar, maka kebutuhan mereka dalam jangka pendek maupun jangka panjang menjadi tidak diperhatikan. Pengembangan filantropi di Indonesia juga belum banyak melibatkan kaum perempuan dalam kegiatan kedermawanan. Berbagai organisasi sosial yang melakukan penggalangan dukungan dan sumber daya juga belum menggali potensi kaum perempuan sebagai donatur dan pendukung program-program sosial kemanusiaan.

Pada era modern sekarang ini, asumsi tersebut tidak sepenuhnya benar, karena saat ini jumlah perempuan yang bekerja di sektor publik dan berpenghasilan tinggi sudah cukup banyak.Peran perempuan di sektor nirlaba di Indonesia juga mengalami perkembangan yang ditandai dengan meningkatnya jumlah perempuan yang terlibat dalam kepengurusan organisasi nirlaba. Kaum perempuan bahkan memegang posisi dan peran yang strategis di berbagai organisasi masyarakat masyarakat. Meningkatnya eksistensi perempuan juga ditandai dengan maraknya berbagai organisasi yang didirikan oleh kaum perempuan dan secara khusus memperjuangkan persoalan dan kepentingan mereka. Fakta di lapangan juga menunjukkan bahwa lembaga-lembaga filantropi yang teruji oleh terpaan waktu adalah filantropi yang didirikan oleh kaum perempuan. 
Hal ini menjadi bukti bahwa eksistensi perempuan dalam melakukan filantropi sangat penting, terutama untuk membangun kemandirian mereka. Kaum perempuan Indonesia mulai sadar dan membangun jaringannya melalui organisasi-organisasi filantropi untuk menemukan ruang keterlibatannya dalam civil society. Keterlibatan kaum perempuan juga menjadi bukti konkret bahwa wilayah kerja perempuan bukan lagi ranah domestik dan privat yang hanya mengurusi urusan rumah tangga semata, tetapi telah menembus ruang publik. Fenomena ini sekaligus membongkar stigma negatif yang melekat pada perempuan sehingga marginalisasi terhadap kaum perempuan berangsur-angsur hilang. Kecenderungan ini diharapkan dapat mendorong kemandirian perempuan sebagai mesin penggerak pengembangan filantropi yang menjadi gerakan sosial dalam masyarakat.

Para pegiat perempuan telah melakukan kegiatan filantropi dengan memobilisasi sumber daya kaum perempuan untuk menolong masyarakat, khususnya perempuan miskin di sekitar mereka, supaya mendapatkan akses ke layanan-layanan dasar yang menjadi hak mereka. Maka dari itu, agar filantropi bisa mengarah pada kemandirian perempuan, hendaknya agenda filantropi mencakup beberapa hal, yaitu: pertama, pemberdayaan ekonomi terhadap perempuan. Hal ini sangat penting karena pemberdayaan ekonomi menjadi wilayah darurat (Farida \& Kasdi, 2018: 150).

Kedua, pemberdayaan pendidikan perempuan. Kaum perempuan secara langsung selalu berinteraksi dengan memperbaiki kualitas dan spiritualitas anak-anak serta keluarga. Selama ini anak-anak dan keluarga merupakan wilayah yang berkaitan erat dengan perempuan. Oleh karena itu diperlukan perempuan yang memiliki kesamaan ide, misi dan visi untuk aksi edukasi dan pemberdayaan 
anak-anak dan keluarga. Ketika perempuan sudah setara dengan laki-laki secara pendidikan, maka ia bisa bersikap mandiri untuk dirinya, anak dan keluarganya.

Ketiga, pemberdayaan aspek kesehatan. Menurut Women Research Institute, kajian tentang pelayanan kesehatan merupakan salah satu masalah yang diidentifikasi dan sering dihadapi oleh perempuan miskin. Mereka tak memiliki akses dalam memanfaatkan fasilitas kesehatan. Masalah tersebut terkait erat dengan fasilitas dan pelayanan kesehatan itu sendiri, keluarga, dan masalah sosial budaya lainnya. Kebijakan publik berkaitan dengan pemenuhan hak-hak mendasar akan memberikan pengaruh pada peningkatan kesejahteraan masyarakat miskin, terutama kaum perempuan.

Dengan demikian, aktivitas filantropi untuk kemandirian perempuan sangat berpotensi jika dilakukan dengan mendorong potensi kaum perempuan sebagai pendukung dan donatur program tersebut. Kaum perempuan dengan beragam potensi yang dimilikinya bisa digerakkan untuk menjadi volunteer, donatur, campaigner, atau bahkan fundraiser untuk lembaga-lembaga sosial dan nirlaba. Filantropi kaum perempuan ini bahkan berpotensi untuk digalang guna mengatasi berbagai persoalan sosial di Indonesia, khususnya persoalan-persoalan yang dihadapi kaum perempuan Indonesia.

\section{Perempuan Melalui Filantropi sebagai Agen Perubahan Sosial}

Berkembangnya filantropi perempuan dalam kurun waktu belakangan ini merupakan fenomena positif bagi kaum perempuan khususnya, dan bagi masyarakat Indonesia pada umumnya. Perkembangan ini semakin menarik bagi masyarakat Indonesia karena ia terjadi di tengah perubahan sosial politik menuju tatanan baru 
yang lebih demokratis. Hal ini penting karena dua alasan; pertama, perkembangan filantropi yang bagus dengan sendirinya dapat mendukung perwujudan masyarakat sipil yang kuat, mandiri dan sejahtera. Kedua, pencapaian tersebut akan memberi arti penting bagi penguatan agenda reformasi, demokratisasi dan transformasi sosial di Indonesia (Bamualim \& (ed.), 2005: v).

Kecenderungan perubahan sosial di masyarakat juga berdampak pada perempuan, seperti kebijakan negara dalam privatisasi layanan publik dan bertambahnya angka kemiskinan, yang berarti juga meningkatnya jumlah perempuan yang miskin. Sebaliknya, program kegiatan filantropi yang bertujuan untuk mengentaskan kemiskinan di masyarakat juga berdampak secara positif dalam mengurangi kemiskinan kaum perempuan (Enarson, 2003).

Perubahan paradigma filantropi perempuan jelas terlihat dari perubahan mendasar yang sedang berlangsung, dari tradisi karitatif menuju tradisi baru yang mencoba menggunakan pendekatan baru dalam menyelesaikan masalah sosial, yaitu mengatasi masalah dari akarnya secara terencana, berjangka panjang dan terukur. Ini artinya filantropi Islam tidak lagi dipraktikkan sebatas pemberian makanan, minuman, pakaian, atau pembangunan masjid, melainkan lebih dari itu, filantropi perempuan berupaya membangun manusianya dengan cara pemberdayaan ekonomi, perhatian pada dunia kesehatan, pendidikan, lingkungan dan sebagainya.

Kedermawanan perempuan memberikan kontribusi yang signifikan baik secara sosial maupun ekonomi. Dalam bidang kesehatan dan ekonomi, peran keperawatan perempuan dalam bidang maternal bagi ibu dan anak yang diwujudkan dalam bentuk posyandu terbukti mengurangi subsidi pemerintah terhadap bidang ekonomi. Sedangkan dampak sosial yang muncul dari peran kedermawanan 
perempuan adalah terciptanya masyarakat yang lebih sensitif dan peduli terhadap kepentingan sesama (Fatimah, 2008: 1). Bahkan kedermawanan perempuan dalam banyak kasus bencana yang terjadi di Indonesia menunjukkan signifikasi peran perempuan sebagai agen perubahan sosial.

Peran dalam mendesain dan merencanakan kegiatan filantropi yang dilakukan kaum perempuan, sangat mendukung keberhasilan filantropi yang mereka lakukan. Perempuan mempunyai modal sosial yang alami menjadi seorang relawan. Semangat filantropi di kalangan perempuan yang sudah teruji, ternyata juga terkait erat dengan pengalaman keseharian mereka. Melalui kegiatan filantropi yang dilaksanakan oleh kaum perempuan dalam kurun waktu yang lama memberi bukti bahwa perubahan sosial itu akan dan telah terjadi.

Gagasan dan uluran tangan yang terampil dari perempuan kreatif memperkuat keyakian bahwa perubahan sosial melalui filantropi kaum perempuan sangat signifikan dalam membawa angin perubahan bagi warga masyarakat yang membutuhkan. Para perempuan sanggup menjadi aktor-aktor filantropis yang mempunyai kekuatan untuk menopang orang-orang di sekitarnya yang membutuhkan. Kemampuan yang dimiliki perempuan untuk menggerakkan perubahan sosial melalui filantropi tidak hanya dimonolopi oleh kelas menengah saja, melainkan juga dimiliki oleh kaum perempuan kelas bawah (Abidin, 2008:169).

Tujuan yang hendak dicapai adalah filantropi untuk perubahan sosial yang merupakan kontibusi penting bagi kaum perempuan yang memahami bagiamana dan mengapa perubahan sosial ini terjadi, termasuk ketimpangan sosial, dan alternatif yang dapat dicari untuk solusi pemberdayaan perempuan dalam menghadapi 
perubahan sosial. Untuk tujuan ini, Faber dan McCarthy mengusulkan agar filantropi dilakukan oleh organisasi perempuan yang bergerak di bidang pendidikan yang menyiapkan generasi muda yang progresif. Tentunya ada kontrol terhadap penggunaan dana filantropi tersebut agar berjalan baik dan tujuannnya tercapai dengan maksimal (Faber \& McCarthy (ed.), 2005: 283).

\section{Simpulan}

Kegiatan filantropi yang dilaksanakan oleh para perempuanmemberimaknatentangeksistensiperempuan yang mempunyai kemampuan menyelenggarakan sekian jenis pekerjaan dan menciptakan ruang lebih luas untuk mengajak setiap orang, baik laki-laki ataupun perempuan, mengurus bukan hanya kesejahteraannya sendiri, melainkan juga kesejahteraan masyarakat. Peran perempuan dalam kegiatan filantropi menunjukan adanya pemberdayaan perempuan dalam gerakan membangun masyarakat yang lebih tertata di negeri ini. Filantropi untuk kemandirian perempuan sangat relevan dilakukan dengan mendorong potensi kaum perempuan sendiri sebagai pendukung program tersebut. Kaum perempuan dengan berbagaikelebihan yang dimilikinya dapat digerakkan menjadi donatur bagi lembaga-lembaga nirlaba dan sosial. Filantropi kaum perempuan ini bahkan berpotensi untuk digalang guna mengatasi berbagai persoalan sosial di Indonesia, khususnya persoalanpersoalan yang dihadapi kaum perempuan dan masyarakat Indonesia.

Perempuan mempunyai modal sosial yang alami menjadi seorang relawan. Semangat filantropi di kalangan perempuan yang sudah teruji, juga terkait erat dengan pengalaman keseharian mereka. Melalui kegiatan 
filantropi yang dilakukan oleh perempuan dalam kurun waktu yang lama memberi bukti bahwa perubahan sosial itu akan dan telah terjadi. Untuk menguatkan eksistensi kaum perempuan, kegiatan filantropi yang mereka lakukan kaum perempuan hendaknya juga mengarah pada upaya memperkuat kepemimpinan perempuan dan memperkuat organisasi-organisasi perempuan yang konsen pada isu gender. Demikian juga, meningkatkan keterwakilan perempuan dalam lembaga pengambil keputusan untuk mempengaruhi kebijakan-kebijakan pemerintah, peraturan-peraturan dan kualitas layanan dasar, agar memenuhi kebutuhan perempuan secara lebih proporsional. 


\section{DAFTAR PUSTAKA}

Abidin, Z. (2008). Para Perempuan Dermawan; Potret Enam Pelaku Filatropi. Jakarta: PIRAC (Public Interest Research and Advocacy Center).

Bakar, I. A., \& Bamualim (ed.), C. S. (2006). Filantropi Islam dan Keadilan Sosial: Studi tentang Potensi, Tradisi, dan Pemanfaatan Filantropi Islam di Indonesia. Jakarta: The Ford Foundation dan CSRC.

Bamualim, C. S., \& (ed.), I. A. B. (2005). Revitalisasi Filantropi Islam: Studi Kasus Lembaga Zakat dan Wakaf di Indonesia. Jakarta: Pusat Bahasa dan Budaya (PBB) UIN Syarif Hidayatullah.

Borgatta, E. F., \& Borgatta (ed.), M. L. (1984). Encyclopedia of Sociology. New York: Macmillan Publishing Company.

Conger, J. A., \& Kanungo, R. N. (1988). The Empowerment Process: Integrating Theory and Practice. Jurnal The Academy of Management Review, 13(03).

Depag, D. P. W. (2006). Data Aset Wakaf di Indonesia. Jakarta: Depag RI.

Echols, J. M., \& Shadily, H. (1983). Kamus Inggris-Indonesia. Jakarta: Gramedia Pustaka Utama.

Enarson. (2003). Working with Women at Risk: Practical Guidelines for Assessing Local Disaster Risk. Florida: Florida International University, International Hurricane Center.

Faber, D. R., \& McCarthy (ed.), D. (2005). Foundations for Change: Critical Perspectives on Philantrhropy and Popular Movements. Lantam MD: Rowman and Littlefield. 
Farida, U., \& Kasdi, A. (2018). The 2017 KUPI Congress and Indonesian Female 'Ulama. Journal of Indonesian Islam (JIIS), 12(02), 135-158. https://doi.org/10.15642/ JIIS.2018.12.2.135-158

Fatimah, D. (2008). Bencana dan Kerelawanan Perempuan Diffabel. Galang; Jurnal Filantropi Dan Masyarakat Madani, 03(01).

Fauzia, A. (2017). Islamic Philanthropy in Indonesia: Modernization, Islamization, and Social Justice. Austrian Journal of South-East Asian Studies, 10(02), 223236.

Gandi, L. (1998). Postcolonial Theory: A Critical Introduction. Australia: Allen and Unwin.

Hidayah, A. (2018). Wawancara tentang Pembentukan dan Peran DESBUMI (Desa Peduli Buruh Migran).

Hoexter, M. (2003). Charity, the Poor, and Distributionof Alms in Ottoman Algiers. In et. al. (ed) M. Bonner (Ed.), Poverty and Charity in Middle Eastern Contexts. New York: State University of New York Press.

Ilchman, W. F. (eds. . (2006). Philanthropy in the World Traditions (Filantropi di Berbagai Tradisi Dunia). Jakarta: Center for the Study of Religion and Culture (CSRC).

Kasdi, A. (2016). Filantropi Islam Untuk Pemberdayaan Ekonomi Umat ( Model Pemberdayaan ZISWAF di BMT Se-Kabupaten Demak ), 9(2), 227-245.

Kasdi, A. (2018). The Empowerment of Productive Waqf in Egyptian Al-Azhar for Education and its Relevance to be Implemented in Indonesia. International Journal of Mechanical Engineering and Technology (IJMET), 9(11), 
1839-1851.

Klein, K. (2001). Fundraising for Social Change. Oakland California: Chardon Press.

Maslow, A. (1970). Motivation and Personality. New York: Harper and Row.

Muhajir, N. (1994). Metodologi Penelitian Kualitattif. Yogyakarta: Rieke Sarasin.

Neufeldt, V. (ed. . (1984). Webster's New World Dictionary. New York: Webster's New World Clevenland.

Payton, R. L. (1998). Philanthropy; Voluntary Action for the Public Good. McMillan New York: American Council on Education.

Qahaf, M. (2006). Al-Waqf al-Islamy; Tathawwuruhu, Idaratuhu, Tanmiyyatuhu. Syiria: Dar Al-Fikr Damaskus.

Romlawati.(2018). Wawancara tentang PEKKA (Pemberdayaan Perempuan Kepala Keluarga).

Rowlands, J. (1997). Questioning Empowerment: Working with Women in Honduras. Oxford: AXFAM, UK.

Saidi (et.al.), Z. (2002). Membangun Kemandirian Berkarya: Potensi dan Pola Derma, serta Penggalangannya di Indonesia. Jakarta: PIRAC (Public Interest Research and Advocacy Center).

Salim, A. (2003). Pengelolaan Zakat dalam Politik Orde Baru (1968-1998). In Problematika Zakat Kontemporer; Artikulasi Proses Sosial Politik Bangsa. Jakarta: FOZ.

Shabri, I. S. (2008). Al-Waqf Al-Islamy: Baina an-Nazhriyyah wa at-Tathbiq. Yordania: Dar an-Nafais. 
Turner, J. H. (1998). The Structure of Sociological Theory. Wadsworth Publishing Company.

Westy, A. (2008). Kerelawanan: Pilar Pemberdayaan Perempuan yang Semakin Kokoh. Galang; Jurnal Filantropi Dan Masyarakat Madani, 03(01).

Www.mampu.or.id, diunduh pada tanggal 14 Maret 2018 pukul 20.00 WIB. (2018).

Zahrah, A. (2005). Muhadlarah fi al-Waqf. Cairo: Dar al-Fikr al-'Arabi.

Zarkasyi, A. S. (2005). Manajemen Pesantren: Pengalaman Pondok Modern Gontor. Ponorogo: Trimurti Press. 